\title{
Seminar Program Kerja Desa
}

INDAH

NIM : 9173770410290

Email : ndahbakwan07@gmail.com

\section{Bentuk Kegiatan}

Gotong Royong Dikantor Desa

2. Lokasi

Dusun Balngloe Tarowang,Kantor Desa

Balangloe Tarowang. Kec Tarowang, Kab Jeneponto

\section{Hari/Tanggal dan Waktu}

Pada Hari Sabtu tanggal 26 September 2020.

Jam 07:30

4. Peserta yang Dilibatkan

Peserta KKLP.STIE STKIP YAPTI JENEPONTO

5. Alasan Diadakannya

Agar Halaman Kantor Desa Balangloe Tarowang. Terlihat Bersih Dan Rapi
6. Tujuan dan Manfaat

Tujuan : Agar Halaman kantor Desa Bersih

Manfaat : Supaya Penyakit jauh dari kita,semua,kualitas udara lebih baik,

7. Produk Kegiatan (Jika ada)

Sapu Lidi,Sapu iju,kain pel,skop

8. Deskripsi Kegiatan

Pada hari Sabtu. Kami peserta KKLP.bersama-sama ke kantor Desa membawa alat kebersihan masingmasing kegiatan tersebut dilaksanakan pada jam 08:00 di halaman Kantor Desa Balangloe Tarowang kegiatan itu berjalan sekitar 2 jam.

9. Referensi Wajib

- HERIANTO, H., \& Amir, A. S. (2020, September 10). Pedoman Pelaksanaan Kuliah Kerja Lapangan Plus (KKLP) Mahasiswa STIE dan STKIP YAPTI Jeneponto. https://doi.org/10.31219/osf.io/7dvpk 